Prepared in cooperation with the University of lowa IIHR - Hydroscience and Engineering

\title{
Evaluation of the Ott Hydromet Oliner for Measuring Discharge in Laboratory and Field Conditions
}
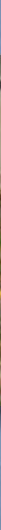

Open-File Report 2015-1052

U.S. Department of the Interior U.S. Geological Survey 
Cover. Left and right photographs: Ott Hydromet Qliner field comparison data collection on the Cedar River at Cedar Rapids, lowa (USGS streamgage 05464500), March 19, 2007. Center photograph: USGS personnel collecting Ott Hydromet Oliner comparison data on the Cedar River at Cedar Rapids, lowa (USGS streamgage 05464500), March 19, 2007.

Background photograph: Ott Hydromet Qliner field comparison data collection on the Cedar River at Cedar Rapids, lowa (USGS streamgage 05464500), March 19, 2007.

All photographs by Clint VanSchepen, USGS. 


\section{Evaluation of the Ott Hydromet Qliner for Measuring Discharge in Laboratory and Field Conditions}

By Jason C. McVay

Prepared in cooperation with the University of lowa IIHR - Hydroscience and Engineering

Open-File Report 2015-1052 


\title{
U.S. Department of the Interior SALLY JEWELL, Secretary
}

\section{U.S. Geological Survey \\ Suzette M. Kimball, Acting Director}

\author{
U.S. Geological Survey, Reston, Virginia: 2015
}

For more information on the USGS - the Federal source for science about the Earth, its natural and living resources, natural hazards, and the environment—visit http://www.usgs.gov or call 1-888-ASK-USGS.

For an overview of USGS information products, including maps, imagery, and publications, visit http://www.usgs.gov/pubprod/.

Any use of trade, firm, or product names is for descriptive purposes only and does not imply endorsement by the U.S. Government.

Although this information product, for the most part, is in the public domain, it also may contain copyrighted materials as noted in the text. Permission to reproduce copyrighted items must be secured from the copyright owner.

Suggested citation:

McVay, J.C., 2015, Evaluation of the Ott Hydromet Oliner for measuring discharge in laboratory and field conditions: U.S. Geological Survey Open-File Report 2015-1052, 13 p., http://dx.doi.org/10.3133/ofr20151052.

ISSN 2331-1258 (online) 


\section{Acknowledgments}

The author would like to acknowledge the collaborative effort that took place with the University of lowa IIHR - Hydroscience and Engineering, specifically Andy Craig and Dr. Marian Muste.

The author also is grateful to the staff of the U.S. Geological Survey lowa Water Science Center who collected field data for this study. The author also thanks Dave Mueller and Mike Rehmel of the U.S. Geological Survey Office of Surface Water for the review of this report. 


\section{Contents}

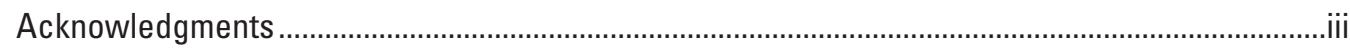

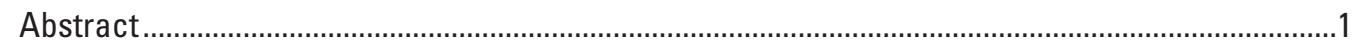

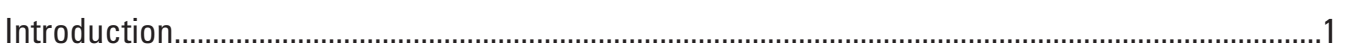

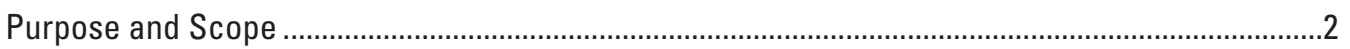

Methods

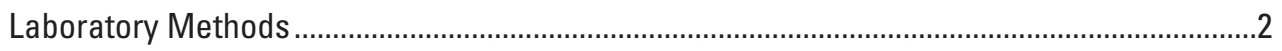

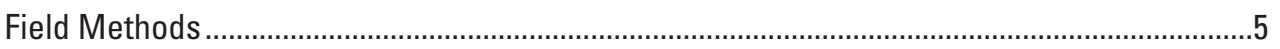

Laboratory Quality-Control and Quality-Assurance Procedures..............................................

Field Comparison Measurements Quality-Control and Quality-Assurance Procedures...........7

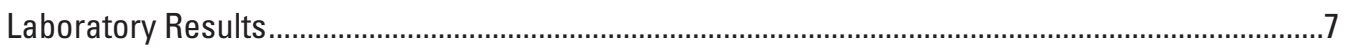

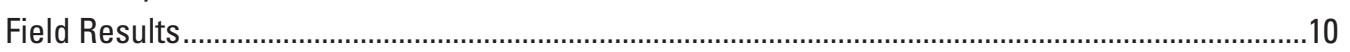

Summary and Conclusions................................................................................................

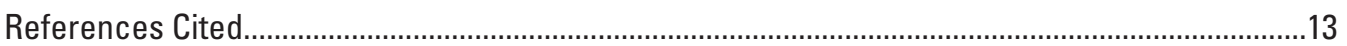

\section{Figures}

1. Plan view of in-beam test series measurement setup ......................................................

2. Schematic of the University of lowa IIHR - Hydroscience and Engineering Environmental Flow Facility ..........................................................................................

3. Schematic of in-axis test series setup ..............................................................................

4. Map showing location of U.S. Geological Survey streamgages where comparison measurements were collected.

\section{Tables}

1. Specifications for the Ott Hydromet 1.0 megahertz Oliner and the Sontek 16 megahertz MicroADV.

2. Selected field sites for collection of Qliner comparison discharge measurement data

3. Dispersion of different exposure time Qliner velocities around the 100-minute mean velocity results with flume water depth of 1.98 meters.

4. Qliner in-axis comparison results with a flume water depth of 1.98 meters, water speed of 0.47 meters per second, and a 40 -second exposure time

5. Qliner in-axis comparison results with a flume water depth of 1.98 meters, water speed of 0.47 meters per second, meters and a 5 -minute exposure time

6. Oliner in-beam comparison results with a flume water depth of 1.98 meters, water speed of 0.47 meters per second, and a 40-second exposure time....

7. Oliner in-beam comparison results with a flume water depth of 1.98 meters, water speed of 0.47 meters per second, and a 5 -minute exposure time

8. Oliner field discharge measurement percent differences from comparison discharge measurements

9. Field Oliner mean velocity, and mean depth measurement percent differences from field comparison methods. 


\section{Conversion Factors}

Inch/Pound to International System of Units

\begin{tabular}{|c|c|c|}
\hline Multiply & By & To obtain \\
\hline \multicolumn{3}{|c|}{ Length } \\
\hline meter $(\mathrm{m})$ & 3.280 & foot $(\mathrm{ft})$ \\
\hline \multicolumn{3}{|c|}{ Area } \\
\hline square meter $\left(\mathrm{m}^{2}\right)$ & 10.763 & square foot $\left(\mathrm{ft}^{2}\right)$ \\
\hline \multicolumn{3}{|c|}{ Volume } \\
\hline cubic meter $\left(\mathrm{m}^{3}\right)$ & 35.314 & cubic foot $\left(\mathrm{ft}^{3}\right)$ \\
\hline \multicolumn{3}{|c|}{ Flow rate } \\
\hline meter per second $(\mathrm{m} / \mathrm{s})$ & 3.280 & foot per second (ft/s) \\
\hline cubic meter per second $\left(\mathrm{m}^{3} / \mathrm{s}\right)$ & 35.314 & cubic foot per second $\left(\mathrm{ft}^{3} / \mathrm{s}\right)$ \\
\hline
\end{tabular}

\section{Abbreviations}

EFF IIHR Environmental Flow Facility

IA WSC lowa Water Science Center

IIHR University of lowa IIHR - Hydroscience and Engineering

$\mathrm{kHz} \quad$ kilohertz

$\mathrm{MHz} \quad$ megahertz

MicroADV Micro Acoustic Doppler Velocimeter

S seconds

TRDI Teledyne RD Instruments

USGS U.S. Geological Survey 



\title{
Evaluation of the Ott Hydromet Oliner for Measuring Discharge in Laboratory and Field Conditions
}

\author{
By Jason C. McVay
}

\section{Abstract}

The U.S. Geological Survey, in collaboration with the University of Iowa IIHR - Hydroscience and Engineering, evaluated the use of the Ott Hydromet Qliner using laboratory flume tests along with field validation tests. Analysis of the flume testing indicates the velocities measured by the Qliner at a 40-second exposure time results in higher dispersion of velocities from the mean velocity of data collected with a 5-minute exposure time. The percent data spread from the mean of a 100-minute mean of Qliner velocities for a 40-second exposure time averaged 16.6 percent for the entire vertical, and a 5 -minute mean produced a 6.2 percent data spread from the 100 -minute mean. This 16.6 percent variation in measured velocity would result in a 3.32 percent variation in computed discharge assuming 25 verticals while averaging 4 bins in each vertical. The flume testing also provided results that indicate the blanking distance of 0.20 meters is acceptable when using beams 1 and 2, however beam 3 is negatively biased near the transducer and the 0.20 -meter blanking distance is not sufficient. Field testing included comparing the measured discharge by the Qliner to the discharge measured by a Price AA mechanical current meter and a Teledyne RDI Rio Grande 1200 kilohertz acoustic Doppler current profiler. The field tests indicated a difference between the discharges measured with the Qliner and the field reference discharge between -14.0 and 8.0 percent; however the average percent difference for all 22 field comparisons was 0.22 , which was not statistically significant.

\section{Introduction}

The U.S. Geological Survey (USGS) has historically used mechanical rotational current meters such as Price AA and pygmy meters to measure discharge. Many alternatives to these meters have been developed over the past 20 years, especially in the area of hydroacoustic technology. The USGS has been using hydroacoustic devices, specifically acoustic Doppler current profilers (ADCPs) attached to manned or tethered boats since the mid-1990s to measure discharge in a variety of conditions (Gotvald and Oberg, 2008). Acoustic Doppler current profilers measure discharge by profiling a cross-section of a channel for water depth and water velocity. This method for measuring discharge can be biased when data are collected during moving bed conditions (Mueller and others, 2013). The use of differential global positioning systems (GPS) is a reliable alternative to ADCP bottom-tracking data for determining boat speed when measuring discharge under moving bed conditions; however, conditions may exist when GPS and ADCP bottom track methods are not reliable and therefore, other alternative devices have been researched.

One such device is the Qliner manufactured by Ott Hydromet (Ott Hydromet, 2006). The Qliner measures velocities passing through the vertical axis of the instrument while it is maintained in a stationary location. The Qliner is capable of averaging velocities from three beams to calculate discharge. Beams 1 and 2 are the primary beams used to determine the mean velocity. Beams 1 and 2 are orientated at an angle of 25 degrees from a vertical position: this angle limits their ability to measure velocity in water less than 0.76 meters $(\mathrm{m})$ (fig. 1). Beam 3 is orientated horizontally at a 20-degree angle and is an optional beam used in data collection that was developed to collect velocity data in water less than $0.76 \mathrm{~m}$. The Qliner uses the mid-section method as described in Rantz and others (1982). The mid-section method is not biased by moving bed conditions because the ADCP is held stationary for each velocity measurement and the velocity measured by the ADCP is only water velocity (Oberg and others, 2005). Using this stationary deployment approach eliminates the biases created from moving bed conditions, because bottom tracking is not required to obtain the correct water velocity.

To evaluate the Qliner for use in measuring discharge, the USGS, in cooperation with the University of Iowa IIHR - Hydroscience and Engineering (IIHR), completed laboratory flume testing and field testing with the device. The flume testing was used to evaluate the measured velocities using beams 1,2 and 3, as well as to evaluate the use of the manufacturer default 0.20-m blanking distance (Nortek-as, 2005). A Sontek MicroADV (Sontek a Xylem Brand, 2015) was used in the flume as the velocity reference instrument (Craig and Muste, 2009). The USGS made discharge measurements in the field using the Qliner, comparing the results to other discharge measurement devices. 


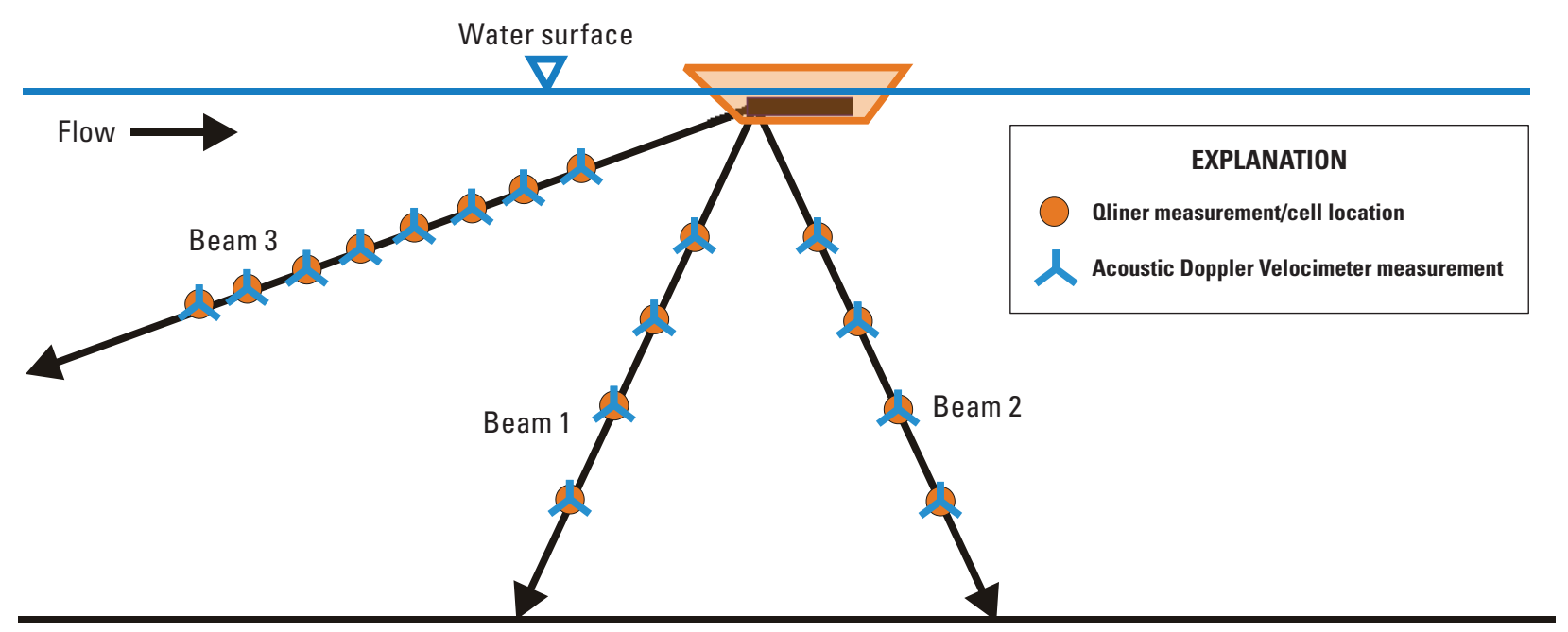

Flume bed

Figure 1. Plan view of in-beam test series measurement setup (Craig and Muste, 2009).

\section{Purpose and Scope}

The purpose of this report is to document the use of the Qliner for making field measurements of velocity and discharge. The first objective was to determine the minimum blanking distance needed to alleviate any bias in velocity measurements caused by signal interference, instrument ringing, and flow disturbance. The second objective addressed in this report was to determine the applicability and conditions of use for inclusion of beam-3 velocity data. The third objective was to determine the appropriate exposure time needed for an accurate measurement of velocity for the use in discharge measurements. Several studies have investigated the importance of exposure time and the effects on uncertainty related to discharge measurement data collection. Three such studies that were used to validate the need to change the USGS policy on discharge data collection methods are described in USGS Office of Surface Water memorandum 2011.08 (U.S. Geological Survey, 2011). Finally, this report provides information regarding the comparability of Qliner discharge measurements with other researched discharge measurement data collection devices. Flume testing and field comparisons were used to document the applicability of using the Qliner as an appropriate device for discharge measurements. A previous study completed by the U.S. Bureau of Reclamation examined the Qliner in laboratory and field settings (Frizell and Vermeyen, 2007). This report adds to the Reclamation study in further, by examining individual cells of velocity data measured by the Qliner as well as evaluating the Qliner in the field in natural channels.

\section{Methods}

This study consists of two principle components: controlled laboratory tests of the Qliner and collection of field data to compare data collected using the Qliner to data collected concurrently using other discharge measurement devices. The IIHR provided the controlled environment flume testing of the Qliner instrumentation at their research facility with equipment and guidance provided by the USGS IA WSC. The USGS IA WSC completed the Qliner field evaluation tests.

\section{Laboratory Methods}

The laboratory tests of the Qliner were carried out in the IIHR Environmental Flow Facility (EFF). The EFF is a recirculating nontilting flume that is $19.81 \mathrm{~m}$ long, $3.05 \mathrm{~m}$ wide and $2.29 \mathrm{~m}$ deep. The maximum flume flow capacity is 3.54 cubic meters per second $\left(\mathrm{m}^{3} / \mathrm{s}\right)$ re-circulated through two $0.91-\mathrm{m}$ pipe lines. Because of the requirement for a freeboard of $0.3 \mathrm{~m}$, the maximum depth of flow available for this study was $1.98 \mathrm{~m}$. Additional information regarding the EFF is described in Craig and Muste (2009). The experimental test area of this study was located $4.27 \mathrm{~m}$ downstream from the raised floor section of the flume. A schematic of the flume and experiment location is shown in figure 2.

The Qliner and Sontek MicroADV were mounted inplace on a traverse across the top of the flume and were stationary throughout the laboratory portion of this study (fig. 3). 

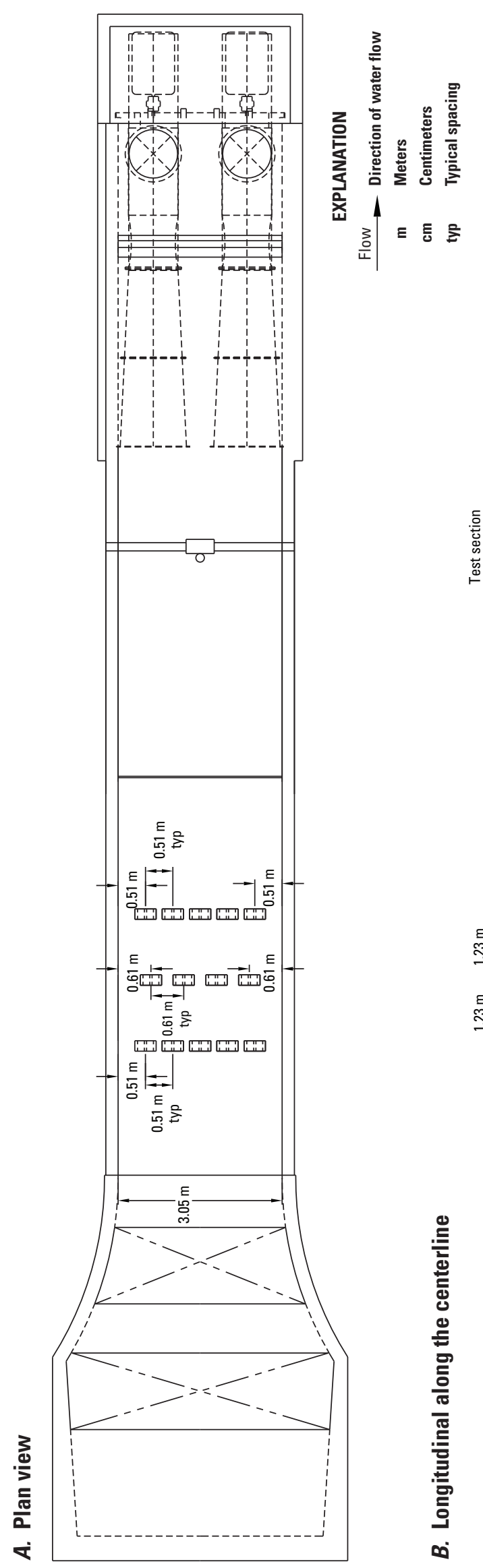

TI foou_
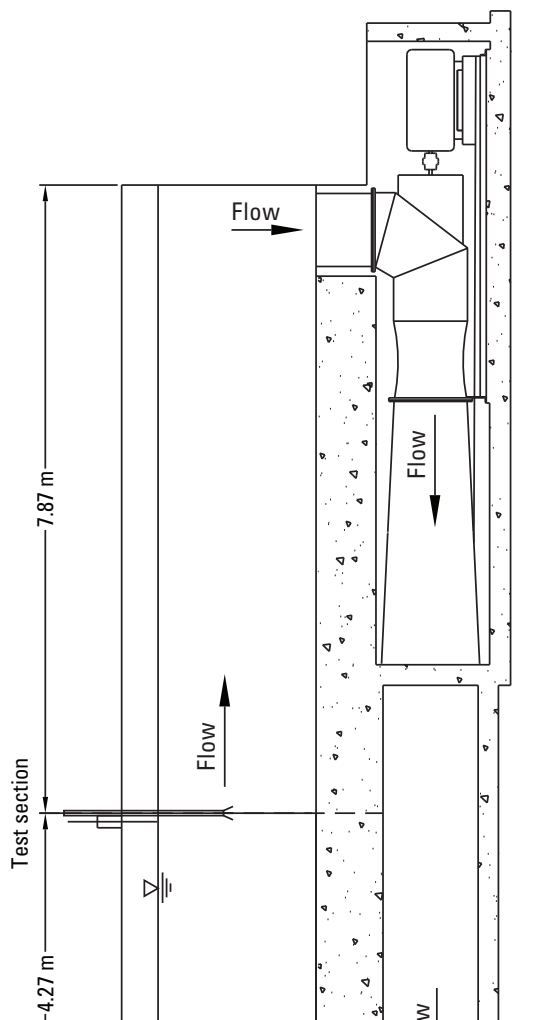

क्户 


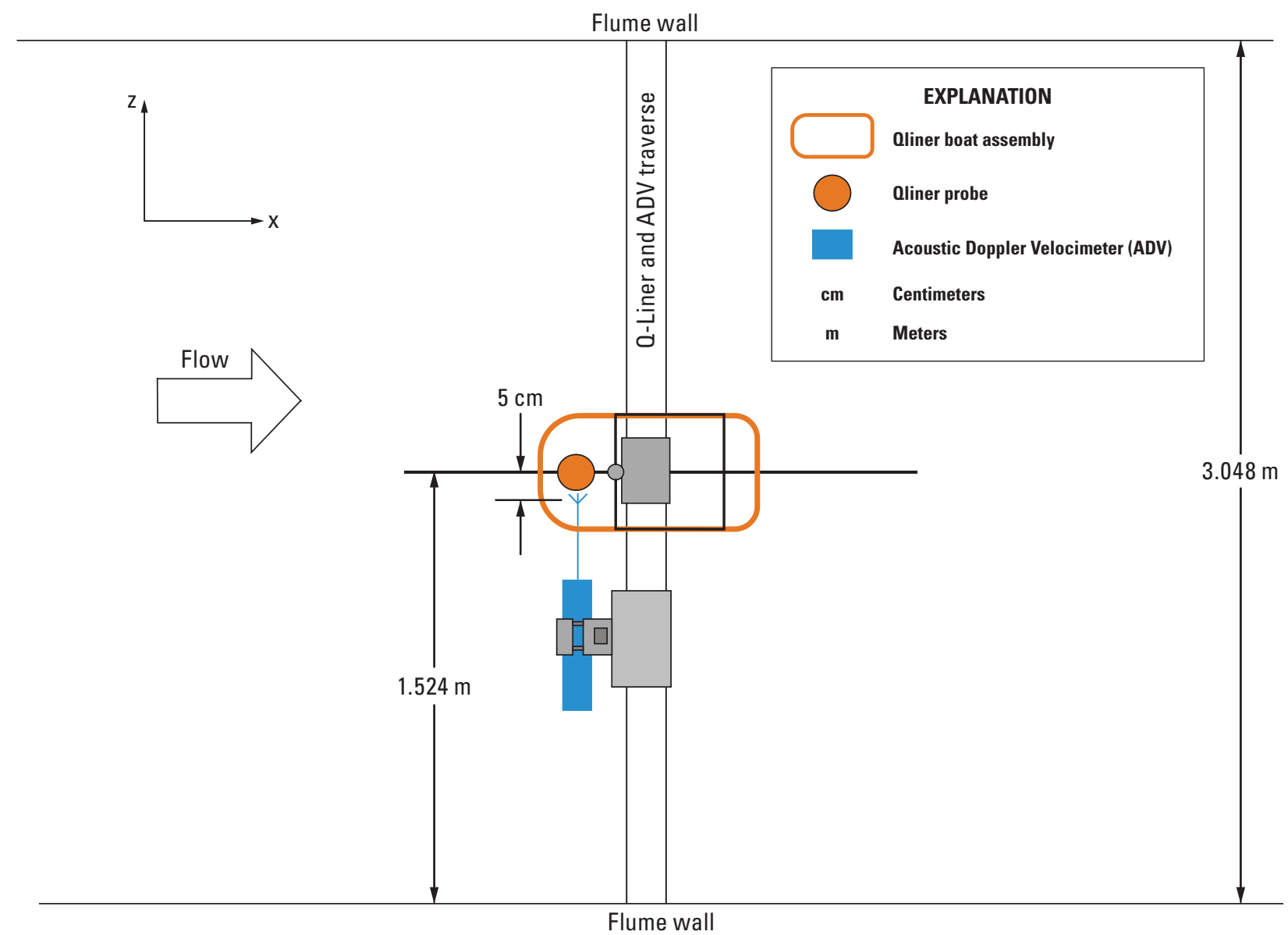

Figure 3. Schematic of in-axis test series setup (Craig and Muste, 2009).

The measurements included in-axis (vertical) and in-beam measurements with the Qliner and MicroADV. The Qliner velocity measurements were compared with the MicroADV velocity measurements (Craig and Muste, 2009).

A Qliner with a frequency of 1 megahertz $(\mathrm{MHz})$ was used in this study. The high-resolution, high-frequency reference instrument for the study was a Sontek MicroADV with a frequency of $16 \mathrm{MHz}$. Specifications of each instrument used in the study are presented in table 1 . The velocity data collected by the Qliner and MicroADV are comparable because both instruments calculate velocity data based on the Doppler principle as described in Simpson and Oltmann (1993).

The first test completed was an in-axis evaluation of the velocities measured by the Qliner. In this test series, the MicroADV and Qliner velocity profiles were measured nonconcurrently at the centerline of the test section in $0.91-\mathrm{m}$, 1.52-m, and 1.98-m depths (Craig and Muste, 2009). For each flow depth, five 5-minute measurements were made with the Qliner mounted to a rigid aluminum frame suspended from a traverse (Craig and Muste, 2009). For all tests, the minimum manufacturer recommended blanking distance $(0.2 \mathrm{~m})$ and minimum cell size $(0.3 \mathrm{~m})$ were selected (Craig and Muste, 2009). The maximum depth setting was set to the actual flow depth plus one cell $(0.3 \mathrm{~m})$ for each set of measurements (Craig and Muste, 2009). The immersion depth was measured at $0.06 \mathrm{~m}$. Sets of consecutive 40 -second measurements were extracted from the 5-minute measurements in post-processing of the data for analysis (Craig and Muste, 2009).

The second test was carried out as an in-beam evaluation of the velocities measured by the Qliner. The MicroADV measurements were made concurrently and located in the centroid of the Qliner velocity measurement cells in beams 1, 2 and 3. The MicroADV measurements were made along the projected beams of the Qliner (fig. 1). To avoid potential interference of the velocity data by concurrently collecting data during the in-beam test, the MicroADV was placed in the beam 3 projected line while recording beam 1 and 2 data, and then the MicroADV was placed in the projected line of beams 1 and 2 while collecting beam 3 data (Craig and Muste, 2009). Thus the accuracy of the comparisons of the MicroADV data and 
the Qliner data is dependent on the assumption that the average flume velocities were uniform for the selected averaging period for the in-beam and in-axis tests ( 5 minutes, 40 seconds). Additional information on the determination of these MicroADV measurement locations is described in Craig and Muste (2009). A total of 15 MicroADV measurements were made corresponding to the 15 Qliner measurement cell locations: 4 measurements in beam 1, 4 measurements in beam 2, and 7 measurements in beam 3 (Craig and Muste, 2009). The same Qliner settings were used during the in-beam test as were used in the in-axis test. A schematic of the in-beam tests is shown in figure 1.

The final laboratory test completed was to determine if incorporating beam 3 into the calculation of the mean velocity produces a bias into a computed discharge measurement. This test was set up to simulate a discharge measurement within the flume setting. Within the flume, there was a known cross-sectional area based on the width and the depth of the water during this test. The reference mean velocity was determined using the $1 / 6$ power law (Craig and Muste, 2009) being applied to the point velocity measurements collected with the MicroADV. The discharge data collected with the Qliner were processed within the Ott Hydromet software QReview version 2.19 (Ott Hydromet, 2007) and compared with the data collected using the MicroADV. The MicroADV velocity data were recorded using the software package Sontek HorizonADV (Craig and Muste, 2009). The MicroADV discharge calculations were made using Microsoft Excel (Microsoft, 2007).

\section{Field Methods}

The field sites were selected at USGS streamgages in Iowa that had stable controls and historically have discharge measurements that result in small deviations from the base stage-discharge relation for the site location. The objective for selecting sites was to minimize the effect of the channel conditions on the results of the discharge measurement data collected. A total of 11 different sites (fig. 4) having varying sizes of drainage areas within Iowa were used to collect the comparison measurement data (table 2).

Field evaluation of the calculation of discharge was completed by USGS personnel following USGS discharge measurement policies that were in place during the time of data collection. Field methods used were based on guidance from the USGS Office of Surface Water Technical Memorandum and reports released before August 2008 (Rantz and others, 1982; U.S. Geological Survey, 2002; and U.S. Geological Survey, 2005). Field data collected using the Qliner followed USGS policy regarding mid-section measurements. This included an exposure time of 40 seconds per vertical as described in Rantz and others (1982).

There were 22 comparison measurements made between February 1, 2006, and August 13, 2008. The comparison discharge measurements were made with Price AA mechanical meters as described in Rantz and others (1982) or with a Teledyne RDI Rio Grande 1200 kilohertz (kHz) ADCP using the moving boat method described in USGS Office of Surface Water Technical Memorandum 2002.02 (U.S. Geological Survey, 2002) and in Oberg and others (2005).

\section{Laboratory Quality-Control and Quality- Assurance Procedures}

Laboratory quality-control and quality-assurance procedures were created to provide a testing environment that would produce unbiased results. The IIHR personnel completed several quality-assurance and quality-control tests before and during the flume study. The initial quality-assurance test was to evaluate the reference instrument (MicroADV) velocity by comparison against a laser Doppler velocimeter before deploying the MicroADV as the reference velocity method for this study. The results for this test verified the velocity measurements collected with the MicroADV (Craig and Muste, 2009). Secondly to verify the flow in the flume within the area of the

Table 1. Specifications for the Ott Hydromet 1.0 megahertz Qliner and the Sontek 16 megahertz MicroADV.

[MHz, megahertz; $\mathrm{m}$, meters; $\mathrm{cm}^{3}$, cubic centimeters; m/s, meters per second; +/-, plus or minus]

\begin{tabular}{lcccccc}
\hline $\begin{array}{c}\text { Velocity } \\
\text { instrument }\end{array}$ & $\begin{array}{c}\text { Transducer } \\
\text { frequency } \\
(\mathbf{M H z})\end{array}$ & $\begin{array}{c}\text { Maximum } \\
\text { water depth } \\
(\mathbf{m})\end{array}$ & $\begin{array}{c}\text { Cell size } \\
\left(\mathbf{c m}^{3}\right)\end{array}$ & $\begin{array}{c}\text { Minumum blanking } \\
\text { distance } \\
(\mathbf{m})\end{array}$ & $\begin{array}{c}\text { Velocity } \\
\text { measurement range } \\
(\mathbf{m} / \mathbf{s})\end{array}$ & $\begin{array}{c}\text { Manufacturer stated } \\
\text { accuracy } \\
(\mathbf{m} / \mathbf{s})\end{array}$ \\
\hline Qliner $^{\mathrm{a}}$ & 1 & 20 & variable & $0.1^{\mathrm{c}}$ & $+/-10$ \\
MicroADV $^{\mathrm{b}}$ & 16 & 60 & 0.09 & 0.05 & 0.001 to 2.5 & 0.05 \\
\hline
\end{tabular}

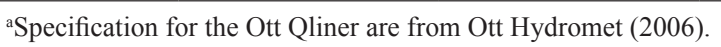

${ }^{b}$ Specifications for the Sontek $16 \mathrm{MHz}$ MicroADV (2005).

${ }^{\mathrm{c}}$ At the time of the study a minumum blanking distance of $0.2 \mathrm{~m}$ was the recommended specification (Nortek-as, 2005). 
Qliner was free from pulsating and variable velocities, the flow was evaluated though a series of measurements made with the MicroADV and the Qliner. The results from this testing verified that the flow did not show pulsating or varying velocities throughout the footprint of the Qliner (Craig and Muste, 2009).

The next quality-assurance test completed was to verify that the velocity measurements made by the Qliner were not affected by the flume environment. The test was created to compare similar velocity and depth measurements for a field environment to the same conditions in the flume. The Qliner data collected in the field were 10 consecutive 5-minute stationary measurements of velocity and depth. These field data were collected by USGS and IIHR staff at the USGS streamgage Iowa River at Iowa City, IA (05454500). The flume environment was then set up to reproduce the same velocity and depth observed during the field data collection. The computed errors and scattering were comparable for the field, and therefore indicated there was no interference between the Qliner and flume (Craig and Muste, 2009).

Lastly, to eliminate any potential errors that may be attributed to an improperly functioning Qliner, a second Qliner was used to perform the same tests as the initial Qliner. The second Qliner in this test was a similar profiler with the same frequency as the initial Qliner. The two Qliners demonstrated comparable behavior in terms of deviations from the reference profile. The results of this test are reported in Craig and Muste (2009).

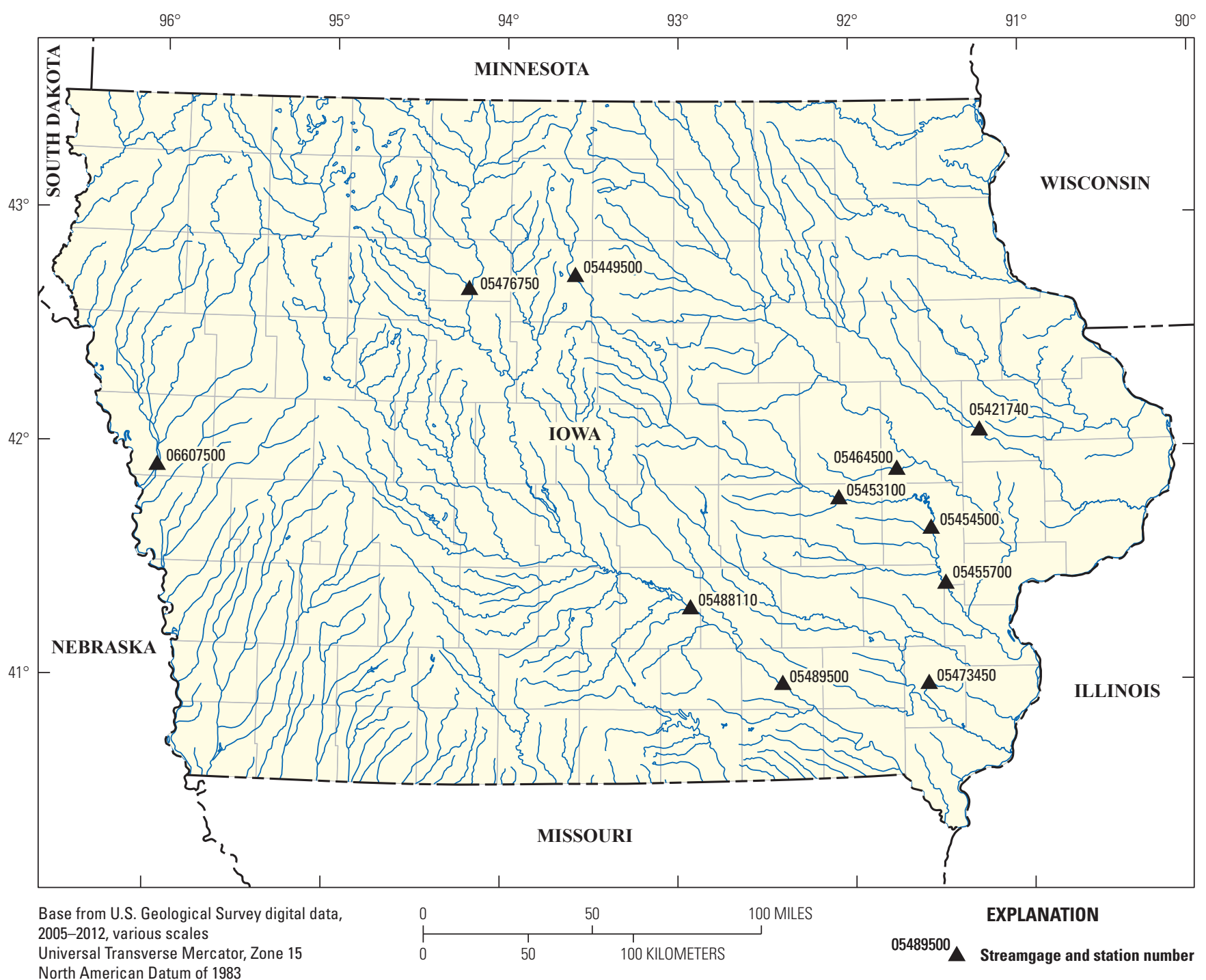

Figure 4. Location of U.S. Geological Survey streamgages where comparison measurements were collected. 


\section{Field Comparison Measurements Quality- Control and Quality-Assurance Procedures}

The quality-control and quality-assurance methods used for the comparison testing of the Qliner field-computed discharge are similar to those used by the USGS for testing other acoustic instrumentation. These methods were developed from previously developed USGS test plans for acoustic instrumentation as discussed in the USGS Office of Surface Water Technical Memorandum 2005.05 (U.S. Geological Survey, 2005).

Two methods were used to compare the discharge measured by the Qliner. These methods were a comparison to a Price AA mechanical current meter measurement or a comparison with a Rio Grande $1200 \mathrm{kHz}$ ADCP acoustic measurement device used by the USGS. The comparison method used was determined on the availability of equipment to collect data. When a mechanical meter was used, mid-section measurement techniques described in Rantz and others (1982) were followed. Measurements with a Rio Grande $1200 \mathrm{kHz}$ ADCP followed methods described in USGS Office of Surface Water Technical Memorandum 2002.02 (U.S. Geological Survey, 2002) and in Oberg and others (2005). Measurements with either a mechanical current meter or an acoustic device were made as close as possible in time to the Qliner measurement at the same location.

\section{Laboratory Results}

The laboratory results used in this report document the comparability of the velocities collected by the Qliner to the reference velocity from the MicroADV. The dispersion of the velocities around the mean collected by the Qliner in the flume also was analyzed.

From the comparative analysis, several important objectives described in the Purpose and Scope section were addressed. The first of which was analyzing potential flow disturbance around the transducers to determine a minimum blanking distance for the Qliner. The results indicated that for beams 1 and 2, a blanking distance of $0.20 \mathrm{~m}$ was sufficient because the first cell reported $(0.58 \mathrm{~m})$ for the collection of velocity data was beyond the area of flow disturbance from the Qliner hull. Because of the bin size and angle of beam 1 and 2 , the first velocity cell is collected outside of the area affected by the hull. However, beam 3 collects data closer to the hull of the Qliner; with a $0.20 \mathrm{~m}$ blanking distance, beam 3 reports the first cell at $0.26 \mathrm{~m}$ which is not sufficient resulting in a low bias in the near surface cells. If beam 3 is included in the collection of the velocity data, the overall velocity data would be negatively biased. This increased effect from the hull is attributed to the bin size and angle orientation of beam 3 on the transducer of the Qliner as beam 3 is collecting data closer to the hull.

The raw velocity data from the Qliner also were analyzed to determine an optimum exposure time for reporting velocity in the use of discharge measurement calculations. Data collected for the flume velocity validation quality-assurance test were also used to analyze the dispersion of the velocities collected by the Qliner. Velocity data were collected for a total of 100 minutes and the mean velocity from this 100 -minute average was used as the true velocity in the calculation of percent data spread, which is also known as coefficient of variation. The data were then separated into 5-minute and 40 -second exposure times. The standard deviation of the Qliner velocity data from each bin in the profile for each of

Table 2. Selected field sites for collection of Qliner comparison discharge measurement data.

[USGS, U.S. Geological Survey; km², square kilometers]

\begin{tabular}{clcc}
\hline $\begin{array}{c}\text { USGS streamgage number } \\
\text { (fig. 4) }\end{array}$ & \multicolumn{1}{c}{ USGS streamgage name } & $\begin{array}{c}\text { Drainage area } \\
\left(\mathbf{k m}^{\mathbf{2}} \boldsymbol{(}\right)\end{array}$ & $\begin{array}{c}\text { Number of } \\
\text { comparisons made }\end{array}$ \\
\hline 05489500 & Des Moines River at Ottumwa, Iowa & 8,739 & 1 \\
05453100 & Iowa River at Marengo, Iowa & 7,236 & 1 \\
05473450 & Big Creek North of Mt. Pleasant, Iowa & 8,472 & 7 \\
05454500 & Iowa River at Iowa City, Iowa & 16,860 & 1 \\
05464500 & Cedar River at Cedar Rapids, Iowa & 4,079 & 1 \\
05421740 & Wapsipinicon River near, Anamosa, Iowa & 5,843 & 1 \\
05476750 & Des Moines River at Humbolt, Iowa & 1,111 & 1 \\
05449500 & Iowa River near Rowan, Iowa & 31,934 & 1 \\
05488110 & Des Moines River near Pella, Iowa & 11,118 & 1 \\
05455700 & Iowa River near Lone Tree, Iowa & 9,132 & 6 \\
06607500 & Little Sioux River near Turin, Iowa & \\
\hline
\end{tabular}


these 5-minute and 40-second exposure times was determined (Helsel and Hirsch, 2002). This standard deviation was then divided by the 100 -minute mean velocity to determine the percent data spread. The results presented in table 3 verify that the shorter exposure time results in a higher dispersion from the 100-minute mean velocity. The mean percent data spread of all of the bins collected in the profile for the 40 -second data was 16.6 percent, as compared to the mean percent data spread of 6.2 percent for the 5-minute data.

Furthermore, a random error was calculated from the mean percent data to associate the variation in velocity to the data collected during a mid-section discharge measurement. A typical USGS mid-section measurement would contain at least 25 verticals while collecting velocities for 40 seconds at each vertical (Rehmel, 2007). A random error associated with the velocities collected by the Qliner can be calculated by dividing the mean percent data spread by the square root of the number of verticals or samples. A random error or uncertainty of 3.32 percent from a 100-minute mean Qliner velocity can be expected when collecting 25 verticals with a 40 -second exposure time for each vertical.

The comparisons made between the Qliner and the MicroADV during the in-axis laboratory tests also indicated that a longer exposure time will result in Qliner mean velocities with less dispersion from the mean MicroADV velocity. The results from the in-axis tests were similar to the in-beam tests. The results from the in-axis test at a depth of $1.98 \mathrm{~m}$ and a velocity of $0.47 \mathrm{~m} / \mathrm{s}$ are presented in tables 4 and 5 . The results in table 4 indicate that when the Qliner velocity data are collected using a 40 -second exposure time, the mean percent data spread from the mean MicroADV velocity is
20.3 percent. The results in table 5 indicate that when exposure time is increased to 5 minutes, the mean percent data spread between the Qliner and the MicroADV decreases to 6.6 percent.

The in-beam tests also indicate a longer exposure time would be needed for the collection of more precise velocity data with the Qliner. The in-beam testing results provided similar percent differences as the in-axis tests. The data show that a longer exposure time will decrease the variability in the velocity data and result in a more precise measurement of the velocity. The results of the 40-second exposure time resulted in a mean percent data spread from the MicroADV of 21.1 percent (table 6 ). The results of the 5-minute exposure time resulted in a mean percent data spread of 6.2 percent (table 7).

The in-beam and in-axis tests revealed that a longer exposure time would result in less variation in velocity. Table 3 also shows a larger variation in velocity when collecting velocity data over a shorter averaging period. This increased variation associated with shorter averaging periods would indicate that there are fluctuations in flow caused by turbulence found in a natural flow environment over a period longer than $40 \mathrm{sec}-$ onds. However, when averaged over the vertical and assuming that 25 verticals are collected during a typical mid-section discharge measurement, the variation in measured discharge would be on the order of plus or minus 3.32 percent. Despite the fact that there are large differences in the sample volume between the Qliner and the MicroADV, the results of a similar comparison indicated only slightly larger variation in the velocities when used in a mid-section discharge measurement.

Table 3. Dispersion of different exposure time Qliner velocities around the 100-minute mean velocity results with flume water depth of 1.98 meters.

$[\mathrm{m}$, meters; $\mathrm{m} / \mathrm{s}$, meters per second]

\begin{tabular}{|c|c|c|c|c|c|c|}
\hline $\begin{array}{l}\text { Bin depth } \\
(\mathrm{m})\end{array}$ & $\begin{array}{l}\text { Beams } \\
\text { tested }\end{array}$ & $\begin{array}{c}\text { Oliner } \\
\text { 100-minute } \\
\text { mean velocity } \\
(\mathrm{m} / \mathrm{s})\end{array}$ & $\begin{array}{c}\text { Oliner percent data } \\
\text { spread from the } \\
\text { 100-minute mean } \\
\text { velocity } \\
\text { (5-minute } \\
\text { exposure time) }\end{array}$ & $\begin{array}{l}\text { Oliner percent data } \\
\text { spread from the } \\
100 \text {-minute mean } \\
\text { velocity } \\
\text { (40-second } \\
\text { exposure time) }\end{array}$ & $\begin{array}{l}\text { Percent data spread } \\
\text { random error when } \\
\text { collecting } 25 \text { verticals } \\
\text { (5-minute } \\
\text { exposure time) }\end{array}$ & $\begin{array}{l}\text { Percent data spread } \\
\text { random error when } \\
\text { collecting } 25 \text { verticals } \\
\text { (40-second } \\
\text { exposure time) }\end{array}$ \\
\hline 0.59 & 1,2 & 0.451 & 5.9 & 13.6 & 1.17 & 2.72 \\
\hline \multirow[t]{2}{*}{1.49} & 1,2 & 0.383 & 5.6 & 12.8 & 1.12 & 2.56 \\
\hline & & & Mean & 16.6 & 1.24 & 3.32 \\
\hline
\end{tabular}


Table 4. Qliner in-axis comparison results with a flume water depth of 1.98 meters, water speed of 0.47 meters per second, and a 40-second exposure time.

$[\mathrm{m}$, meters; $\mathrm{m} / \mathrm{s}$, meters per second]

\begin{tabular}{cccccc}
\hline $\begin{array}{c}\text { Bin depth } \\
(\mathbf{m})\end{array}$ & $\begin{array}{c}\text { Beams } \\
\text { tested }\end{array}$ & $\begin{array}{c}\text { MicroADV velocity } \\
(\mathbf{m} / \mathbf{s})\end{array}$ & Depth cell & $\begin{array}{c}\text { Maximum percent difference } \\
\text { from MicroADV }\end{array}$ & $\begin{array}{c}\text { Oliner mean percent data spread from } \\
\text { the MicroADV mean velocity }\end{array}$ \\
\hline 0.59 & 1,2 & 0.473 & 1 & 24.9 & 18.5 \\
0.89 & 1,2 & 0.462 & 2 & -18.2 & 12.8 \\
1.19 & 1,2 & 0.442 & 3 & -47.2 & 25.4 \\
1.49 & 1,2 & 0.386 & 4 & -28.0 & 24.4 \\
\hline
\end{tabular}

Table 5. Qliner in-axis comparison results with a flume water depth of 1.98 meters, water speed of 0.47 meters per second, meters and a 5-minute exposure time.

$[\mathrm{m}$, meters; $\mathrm{m} / \mathrm{s}$, meters per second]

\begin{tabular}{cccccc}
\hline $\begin{array}{c}\text { Bin depth } \\
(\mathbf{m})\end{array}$ & $\begin{array}{c}\text { Beams } \\
\text { tested }\end{array}$ & $\begin{array}{c}\text { MicroADV velocity } \\
(\mathbf{m} / \mathbf{s})\end{array}$ & Depth cell & $\begin{array}{c}\text { Maximum percent difference } \\
\text { from MicroADV }\end{array}$ & $\begin{array}{c}\text { Oliner mean percent data spread from } \\
\text { the MicroADV mean velocity }\end{array}$ \\
\hline 0.59 & 1,2 & 0.473 & 1 & -16.5 & 7.1 \\
0.89 & 1,2 & 0.462 & 2 & -13.6 & 6.0 \\
1.19 & 1,2 & 0.442 & 3 & -17.5 & 7.3 \\
1.49 & 1,2 & 0.386 & 4 & 7.8 & 6.1 \\
\hline
\end{tabular}

Table 6. Qliner in-beam comparison results with a flume water depth of 1.98 meters, water speed of 0.47 meters per second, and a 40-second exposure time.

$[\mathrm{m}$, meters; $\mathrm{m} / \mathrm{s}$, meters per second]

\begin{tabular}{cccccc}
\hline $\begin{array}{c}\text { Bin depth } \\
(\mathbf{m})\end{array}$ & $\begin{array}{c}\text { Beams } \\
\text { tested }\end{array}$ & $\begin{array}{c}\text { MicroADV velocity } \\
(\mathbf{m} / \mathbf{s})\end{array}$ & Depth cell & $\begin{array}{c}\text { Maximum percent difference } \\
\text { from MicroADV }\end{array}$ & $\begin{array}{c}\text { Oliner mean percent data spread from } \\
\text { the MicroADV mean velocity }\end{array}$ \\
\hline 0.59 & 1,2 & 0.440 & 1 & -30.9 & 15.1 \\
0.89 & 1,2 & 0.431 & 2 & 28.2 & 19.8 \\
1.19 & 1,2 & 0.406 & 3 & -40.4 & 27.9 \\
1.49 & 1,2 & 0.373 & 4 & 37.1 & 21.6 \\
\hline
\end{tabular}

Table 7. Qliner in-beam comparison results with a flume water depth of 1.98 meters, water speed of 0.47 meters per second, and a 5-minute exposure time.

[m, meters; $\mathrm{m} / \mathrm{s}$, meters per second]

\begin{tabular}{cccccc}
\hline $\begin{array}{c}\text { Bin depth } \\
(\mathbf{m})\end{array}$ & $\begin{array}{c}\text { Beams } \\
\text { tested }\end{array}$ & $\begin{array}{c}\text { MicroADV velocity } \\
(\mathbf{m} / \mathbf{s})\end{array}$ & Depth cell & $\begin{array}{c}\text { Maximum percent difference } \\
\text { from MicroADV }\end{array}$ & $\begin{array}{c}\text { Oliner mean percent data spread from } \\
\text { the MicroADV mean velocity }\end{array}$ \\
\hline 0.59 & 1,2 & 0.440 & 1 & 10.6 & 5.4 \\
0.89 & 1,2 & 0.431 & 2 & 11.8 & 5.8 \\
1.19 & 1,2 & 0.406 & 3 & 13.1 & 6.4 \\
1.49 & 1,2 & 0.373 & 4 & 22.1 & 7.3 \\
\hline
\end{tabular}




\section{Evaluation of the Ott Hydromet Oliner for Measuring Discharge in Laboratory and Field Conditions}

\section{Field Results}

The comparison discharge measurements collected during the field testing period indicated a range in percent difference from the comparison method between -14.0 percent and 8.0 percent (table 8 ), and the standard deviation was 5.15 percent. The mean percent difference was 0.22 percent from the comparison discharge measurements, and the median percent difference was 0.89 percent. Calculations were made using the data located in table 8 . All of the comparison data collected during February 2006 to August 2008 were used in the comparison analysis. Two measurements made in January 2006 and November 2006 with the Qliner were not used because of early software problems. Qliner software problems resulted in significant differences between the discharge computed by the data collection software used in the field and the software that is used in post-processing the data. Updated software versions were developed by the vendor (C. Meijer, written commun., 2006), and these differences were not observed in any of the measurements collected from February 2006 to August 2008.

Mean velocity and depth data also were used to evaluate the Qliner for the collection of discharge measurements (table 9). The range of percent differences from the comparison method of mean velocity was -10.22 percent to 15.21 percent, with a standard deviation of 6.92 . The velocity comparison data mean percent difference was 1.82 , and the median was 1.29 percent different. The range of percent difference from the comparison method of mean depth was -11.69 percent to 16.81 percent, with a standard deviation of 6.30. The Qliner mean depth data had a mean percent difference of 0.70 with a median percent difference of -0.04 .

A statistical analysis comparing the Qliner measured discharge with the comparison measured discharge was completed using a t-test to determine if the mean discharges from each device were statistically different. An f-test was computed to determine if the discharges from each device had equal variances. The $\mathrm{f}$-test indicated the variances are equal. A two-sample t-test of equal variances was completed. A p-value threshold of 5 percent was used in this evaluation for the two-sample t-test. A p-value greater than 5 percent indicates the means of the two sample sets are not statistically different. The t-test results, $p$-value greater than 5 percent, indicated the mean discharge of the Qliner measurements was not statistically different than the comparison measurement, (Helsel and Hirsch, 2002). 
Field Results

11

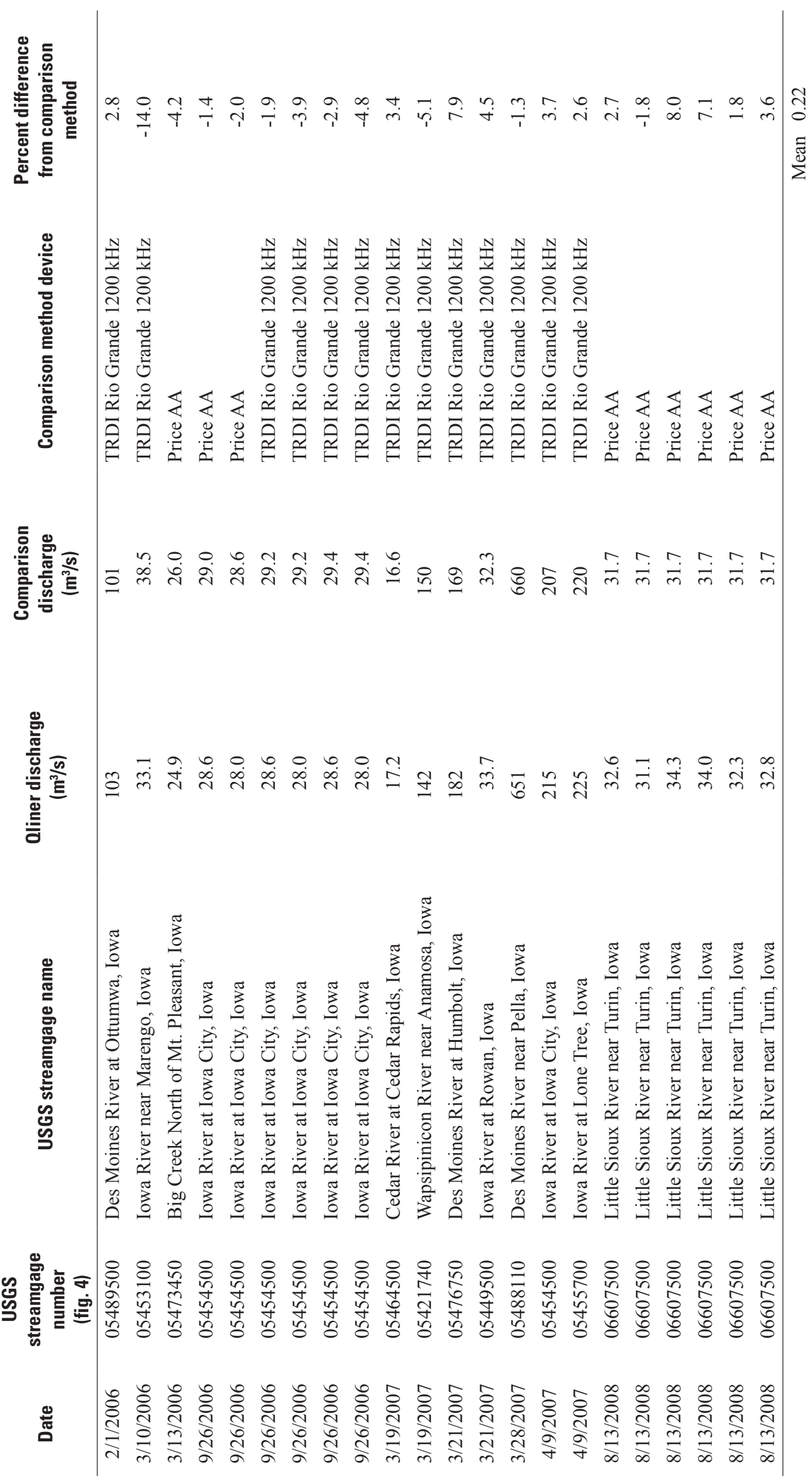




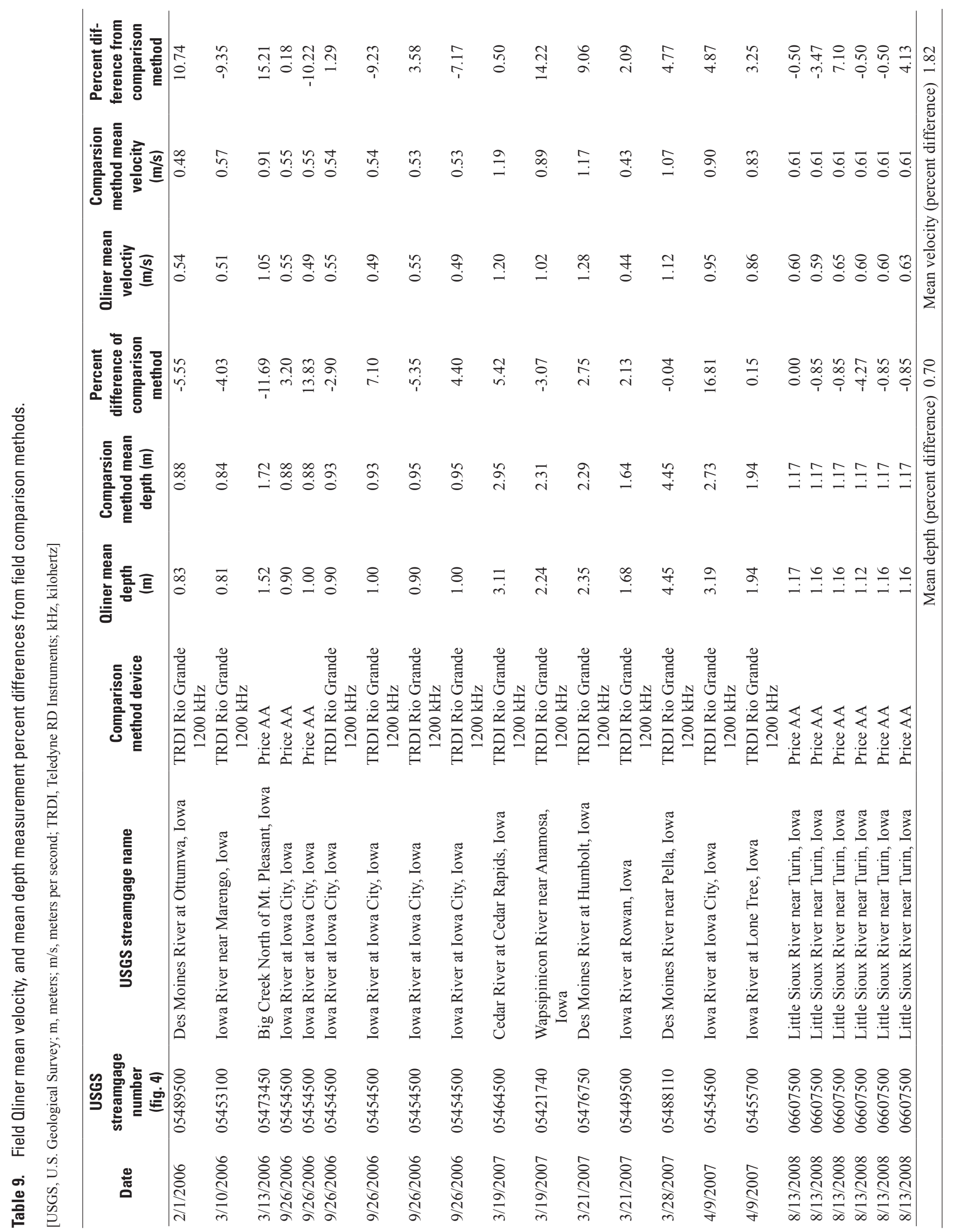




\section{Summary and Conclusions}

The U.S. Geological Survey, in cooperation with the University of Iowa IIHR - Hydroscience and Engineering, evaluated the use of the Ott Hydromet Qliner in laboratory and field conditions. The laboratory testing determined that a $0.20-\mathrm{m}$ blanking distance is sufficient when using beams 1 and 2; when including beam 3, a 0.20 -m blanking distance can produce a negatively biased discharge as beam 3 is measuring unnatural flow disturbance caused by the hull directly in the data collection zone. At the time of this study, the ability for the user to set a blanking distance for beam 3 separate from beams 1 and 2 was not available.

Another important result of this study was the determination of the variability and uncertainty in the Qliner velocity data. The laboratory testing indicated that the velocities measured by the Qliner at a 40-second exposure time results in a higher dispersion from the mean velocity of data collected with a 5-minute exposure time. The Qliner velocity data resulted in a mean percent data spread from a 100-minute mean Qliner velocity of 16.6 percent. This 16.6 percent variation in measured velocity would result in a 3.32 percent variation in computed discharge assuming 25 verticals while averaging 4 bins in each vertical.

The Qliner discharge field data collected during this study did not display any biases or significant deviations from the field comparison measurements. The mean percent difference between the Qliner measured discharge and the comparison discharge was 0.22 , with a range of percent differences from -14.0 and 8.0. Field discharge measurement comparisons verified that the variability in the Qliner velocities for a typical 25 vertical mid-section measurement is less than a single vertical measurement of velocity.

\section{References Cited}

Craig, A., and Muste, M., 2009, Experimental evaluation of the Qliner measurement performance: IIHR Technical Report Series no. 485. [Also available at http://www.iihr. uiowa.edu/wp-content/uploads/2014/05/TR485.pdf.]

Frizell, K.W., and Vermeyen, T.B., 2007, Comparing apples and oranges - Teledyne/RDI StreamPro ADCP and the Ott Qliner river discharge measurement system: U.S Bureau of Reclamation PAP-0965, 5 p., at http://www.usbr.gov/pmts/ hydraulics_lab/pubs/PAP/PAP-0965.pdf.

Gotvald, A.J., and Oberg, K.A., 2008, Acoustic Doppler current profiler applications used in river and estuaries by the U.S Geological Survey: U.S. Geological Survey Fact Sheet 2008-3096, 4 p.
Helsel, D.R., and Hirsch, R.M., 2002, Statistical methods in water resources: U.S. Geological Survey Techniques of Water-Resources Investigations, book 3, chap. A3, 522 p.

Microsoft, 2007, Microsoft Excel for Windows 2007.

Mueller, D.S., Wagner, C.R., Rehmel, M.S., Oberg, K.A, and Rainville, Francois, 2013, Measuring discharge with acoustic Doppler current profilers from a moving boat (ver. 2.0, December 2013): U.S. Geological Survey Techniques and Methods, book 3, chap. A22, 95 p., http://dx.doi. org/10.3133/tm3A22.

Nortek-as, 2005, Aquadopp Profiler specifications brochure, 2 p.

Oberg, K.A., Morlock, S.E., and Caldwell, W.S., 2005, Quality assurance plan for discharge measurements using acoustic Doppler current profilers: U.S. Geological Survey Scientific Investigations Report 2005-5183, 35 p.

Ott Hydromet, 2006, Operating instruction mobile river discharge measurement system Ott Qliner, 70 p.

Ott Hydromet, 2007, Q-Review for Windows user manual $\mathrm{v} 2.1,11 \mathrm{p}$.

Rantz, S.E., and others, 1982, Measurement and computation of streamflow, volume 1, Measurement of discharge: U.S. Geological Survey Water-Supply Paper 2175, 631 p.

Rehmel, M., 2007, Application of acoustic doppler velocimeters for streamflow measurements: Journal of Hydraulic Engineering, v. 133, no. 12, p. 1433-1438.

Simpson, M.R., Oltmann, R.N., 1993, Discharge measurement system using an acoustic Doppler current profiler with applications to large rivers and estuaries: U.S. Geological Survey Water-Supply Paper 2395, 32 p. [Also available at http://pubs.usgs.gov/wsp/wsp2395/.]

Sontek a Xylem Brand (2015), 16-MHZ MicroADV specifications Web page: accessed February 9, 2015, at http://www. sontek.com/productsdetail.php?16-MHz-MicroADV-3.

U.S. Geological Survey, 2002, Policy and technical guidance on discharge measurements using acoustic Doppler current profilers: Office of Surface Water Technical Memorandum 2002.02 .

U.S. Geological Survey, 2005, Guidance on the use of RD Instruments StreamPro Acoustic Doppler Profiler: Office of Surface Water Technical Memorandum 2005.05.

U.S. Geological Survey, 2011, Exposure time for ADCP moving-boat discharge measurements made during steady flow conditions: Office of Surface Water Technical Memorandum 2011.08. 
Publishing support provided by: Rolla Publishing Service Center

For more information concerning this publication, contact: Director, USGS lowa Water Science Center P.O. Box 1230

lowa City, IA 52244

(319) 337-4191

Or visit the lowa Water Science Center Web site at: http://ia.water.usgs.gov/ 



\section{贫
尊}

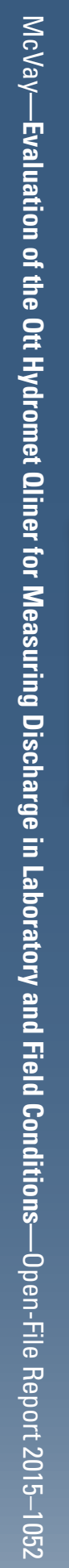

